\title{
Video Mapping for Sea Turtle Preservation Education Campaign
}

\author{
Annisha Muhtadini Fajria ${ }^{a}$ Elda Franzia Jasjfi ${ }^{b}$, Dody Setianto ${ }^{c}$, Tommy Hari Prihatanto ${ }^{d}$ \\ a,b,c,d Visual Communication Design Program, Faculty of Art and Design, Universitas Trisakti, Jakarta, Indonesia \\ belda@trisakti.ac.id
}

Article History: Received: 10 November 2020; Revised 12 January 2021 Accepted: 27 January 2021; Published online: 5 April 2021

\begin{abstract}
This study aims to produce video mapping design concept to educate the topic on sea turtle conservation for all levels of Indonesian societies, especially in the Jakarta Aquarium recreation facilities. Indonesia, a tropical country with variety of natural resources and habitat of the endangered sea turtles required a protection on their habitat by the government. There are 6 types of sea turtles spread across the vast 138 different waters in Indonesia. Efforts of preservation as part of the world's ecosystem need to be done by various parties. The Visual Communication Design, as a major whom proficient in the perceptive communication language has a big role in delivering the message and exploring media for public education about the importance of maintaining the balance of the turtle ecosystem. Video mapping or projection art, is a contemporary technique of delivering information through visual images using lighting and projection so as to produce optical illusions on the object being directed. Through visual communication design method, the result is a video mapping design concept to display a provoking animation meant to visualize the grueling condition and survivability of sea turtles in recent years and to gain awareness for preserving and protecting the natural environment. The video mapping design concept can be used for environmental issues learning materials for youth.
\end{abstract}

Keywords: Video Mapping, Education

\section{Introduction}

Indonesia's biodiversity and natural wealth is a national heritage that needs to be maintained. Environmental damage due to climate change and environmental destruction causes an imbalance of biological and animal ecosystems. Natural resources have a relationship with each other. If one ecosystem is disturbed or lost, it will have an impact on the other ecosystem. Related to this, we need to maintain the sustainability of every existing ecosystem [1]. According to Sustainable Development Goals (SDGs) declared by United Nation and adopted bay all United Nation Member States in 2015, there are an urgent call for action by all countries in global partnership. The Sustainable Development Goal \#14 is to conserve and sustainably use the oceans, seas and marine resources for sustainable [2]. One of the aspects of environmental pollution and climate change is the impact on the disruption of the sea turtle ecosystem. Sea turtles are one of the endangered animals and protected by their habitat by the government. This regulated in Law No. 5 of 1990 concerning Conservation of Biological Resources [3].

Sea turtles are a type of turtle that is spread throughout the oceans in the world, along The Indian Ocean, Pacific Oceans, and South East Asian Sea [4]. Turtles are migratory animals that often move around to find food and lay eggs. They migrate to the nesting area when breeding season is coming. In fact, many of the biggest threats come from humans and their activities, such as turtle eggs, are taken to be used as souvenirs or for consumption. Besides that, warmer climate change also makes several types of turtles born female so that the turtle's reproduction experiences obstacles.

One type of turtle that has habitat in Indonesia is hawksbill (penyu sisik). This type of turtle is the type most often used and has high economic value. According to the UICN Red Data Book, this type of sea turtle is one of the turtles that considers an endangered species. There are 6 types of turtles in Indonesia, namely green turtles or репуи hijau (Chelonia mydas), hawksbill turtles or penyu sisik (Eretmochelys imbricata), leatherback turtles or penyu belimbing (Dermochelys coriaceae), cracked turtles or penyu lekang (Lepidochelys o / iyaceae), flatback turtles or penyu pipih (Natator depressa) and loggerhead turtles or penyu tempayan (Garetta caretta). The turtles are spread in 138 different waters. Kepulauan Seribu, DKI Jakarta is also one of the sea turtles laying beach areas, including Pulau Peteloran Barat and Pulau Peteloran Timur [5]. Sea turtles have an important role in maintaining marine ecosystems. A healthy sea will be a good habitat for millions of fish as a source of protein for humans. For example, one of the green turtles (реnуu hijau) foods is seagrass and seaweed. When sea turtles eat seagrass and seaweed, it will have an impact on seagrass productivity and also add nutrients. Without a constant consumption process, the seagrass plants will grow too lush and it can block the ocean currents so as to result in blocking 
sunlight penetrating to the seabed. As a result, the base of the seagrass will decay and mouldy which in turn will result in disruption of the marine ecosystem [6].

The existence of sea turtles and their problems in their habitat is currently not widely known by the people of Indonesia. Some activities carried out by high school student to raise awareness of the sea turtle's existence. This program attended by students of SMA Negeri 69 Jakarta as community of Pramuka Island, Kepulauan Seribu. They held a Sea Turtle Watch Program on September 2018. This program will help students gained knowledge about sea turtle conservation and leads to higher community understanding of sea turtle's habitat problem [7]. The contribution of waste, the effect of environmental damage and climate change on the survival of sea turtles has not been widely recognized by the public due to the lack of information media and visual media that show the impact of habitat destruction on turtle life. Visual communication design has a role in participating in educating the public about environmental issues, especially sea turtles and their habitats.

Video mapping is one of the information delivery techniques that uses visual images and utilizes lighting and projection technology to create optical illusions on the object being directed. It started as a form of art installation in early 1960s, video installation or video art can be produced and screened on various interfaces and tools nowadays [8]. Video mapping is widely used in various fields, including the economic, entertainment and education sectors. The aim of video mapping is to create a physical illusion of images by combining audio-visual elements of a surface. The use of video mapping can be felt by all levels of society such as children, students and adults, based on the material and the flow of delivery made.

Jakarta Aquarium, is one of the entertainments and educational media in Jakarta, in the form of an indoor aquarium in one of the shopping centers. In collaboration with Aquaria KLCC Malaysia, the Jakarta Aquarium has a one-hectare conservation area and has more than 3500 species of aquatic and non-aquatic animals. Jakarta Aquarium awarded with Trip Excellence's Certificate in 2018 and Destination Indonesia Travel Tourism Award (ITTA) as Conservation Leading Indonesia 2017-2018 and 2018-2019 [9]. Jakarta Aquarium opens for family and peoples from many ages and has 12 attraction zone for entertainment and education. Each zone occupied by different animals. The variety of activity zones are Otter Tunnel, Nurseries of the Sea, Touch Pool, Aqua Trekking, Sea Explorer, Acrylic Walkway, Aqua Camp, Feeding Time Attraction, Interactive 3D Fish, Pearl of the South Sea Theatre, Ocean Wonders, and Pingoo Restaurant. With this conservation area the society will get an interesting information about animals under the sea and from the lands. This video mapping design aims to fill the gap of visual media for sea turtles' conservation education that can attract audience and will utilize the Jakarta Aquarium area.

\section{Research Methodology}

The method used in this study is a qualitative research method. Qualitative research methods are used to provide a description of the design process and results. Support data obtained by the method of survey respondents and observations. The survey is used to provide a basis for the needs of design problems and the media needed by the target audience. Observations were made through searching visual and textual data, from various media and the internet. Alongside, interviews were conducted with informants regarding the problem of damage to marine and sea ecosystems.

The design method is the stage of work carried out to design an object. In designing, certain methods and stages are used to make the design more conceptual and mature. The stages of the design method include 1) PreProduction Phase, which includes preparation stage includes conceptualization, vision, goals, target audience, storyboarding, scheduling, budgeting, and content determination, 2) Production Phase, namely the implementation phase with reference to the results of the previous pre-production stages. The stages of production in making video mapping include making video motion graphics and making sections as media to be directed by the projector, and 3) Post Production Phase, that is the last phase of multimedia phase. This phase including setting or implementation directed using projector to the section so that generate multimedia product which can be seen by the people.

\section{Result and Discussion}

Previous research with the title Campaign for Hawksbill Conservation in the Thousand Islands Region was carried out using a communication strategy that is conscious and encourages entrepreneurs who manage private resorts in the Thousand Islands by using informative and supporting media [10]. In the research, the material presented was in the form of increasing awareness of private resort entrepreneurs to be more concerned about the existence of hawksbill sea turtles, to preserve the conservation function of the islands in the Thousand Islands region as the original habitat for hawksbill turtles, and to increase the participation of the community and the business world to reduce environmental degradation which can have a direct impact on hawksbill sea turtles. The strategy used includes a verbal strategy that is by making a visual tagline. The concept of a creative approach in 
making tagline starts from making the original statement positioning, which is "Maintaining Our Habitat is Maintaining Us to Stay Alive". The visual strategy of using sea turtles as the main object that feels the direct impact of natural damage. The media used include print media such as posters, brochures, flyers, banners, and xbanners. In addition, alternative media and gimmicks are used that are applied to media that have uses such as pocket books, paper borders, train seat covers, pins, shirts and key chains.

Different from the previous design, this particular one uses video mapping as the designated media to reach the target audience. To find out the general understanding of the said preservation threat in Indonesia, a survey conducted to respondents aged 17-50 years with the type of education and employment includes students, fresh graduates, employees, entrepreneurs, to housewives. The survey results showed that $82.2 \%$ of respondents were aware of the threat to the sea turtle population in Indonesia, $66 \%$ of respondents made efforts to reduce the use of plastic in daily life, $82 \%$ of respondents had the habit of disposing garbage in their place, $58 \%$ of respondents had seen a campaign about protecting nature or protecting turtle habitat in Jakarta, 69\% of respondents have never participated in campaign activities about protecting nature or protecting turtle habitat in Jakarta, 59\% of respondents never visited the Jakarta Aquarium in West Jakarta, 38\% of respondents have watched video mapping performances in Indonesia, $67 \%$ of respondents see the video mapping show as an interesting visual experience.

Based on the survey, the sea turtle campaign can be developed using video mapping that can visually attracts target audience. Video mapping is one of the many tools under the realm of multimedia, by means of light projections spatially mapped into a 3D object. According to Vaughan (2004), multimedia is a combination of text, art, sound, images, animation and video delivered by computer or digitally manipulated and can be delivered interactively. Multimedia can be divided into three types, namely interactive multimedia, hyperactive multimedia, and linear multimedia. Interactive multimedia is a type of multimedia where users can control the elements to be used. Hyperactive multimedia is a type of multimedia that has a structure of elements related to the user who can direct it. It can be said that this type of multimedia has many links that connect existing multimedia elements. While linear multimedia is a type of multimedia where users only become viewers and enjoy multimedia products that are served from beginning to end [11].

Video mapping is one of linear multimedia. Video mapping, also called spatial augmented reality, uses lighting techniques or light projections to create optical illusions on objects. Reconstruction of objects in real-world and projection mapping are two techniques to achieve an augmented reality experience [12]. By using certain devices, objects are mapped spatially on virtual programs and mimic the target projection area. Video mapping can be applied to indoor and outdoor objects. The use of video mapping can be a way of recreation by using the right technology to attract the attention of many people. In Indonesia, the use of video mapping attracted attention at the 2018 Asian Games event in Jakarta. The appearance of visual projection objects by using a variety of attractive video and image displays, as well as the use of music and various sound effects add to mood ambience for the duration of the appearance. The use of video mapping not only triggers the target audience to relax with the use of existing technology. Utilization can add to the excitement of the event. Audience who come will get an unusual experience after seeing an amazing visual display. Video mapping is the choice of media to open up new exploration opportunities in marketing and educational communications, especially for urban society.

This video mapping design intend to 1) Educate the society about the threat of sea turtle's extinction, 2) Raise the society awareness to maintain the sea ecosystem balance to avoid sea turtles from extinction, 3) Educate the society about the impact of waste pollution to sea turtle's life. The targets in this design are men and women of all ages, who visit the Jakarta Aquarium recreation facilities. These targets' psychography are those who have a lifestyle that is adaptive to trends and advanced urban life, and likes to visit shopping centers and recreation centers. The targets are open-minded towards technology and science, and have a curiosity about the marine life and the environment, knowing or not knowing about the critical population of sea turtles and the destruction of marine ecosystems in Indonesia.

The process of making video mapping is done through several stages. The first stage is the process of selecting an image or video to be projected. The selected image or video is then projected onto the surface that has been targeted or on a cross section. Video mapping is done in 3D by projecting images on the entire surface of the cross section. Then the masking process is done using template opacity to manipulate the original shape of the position of elements that are different from the area to be projected. In video mapping, the determination of coordination is carried out to determine the location of objects according to the projector, the position and specifications of the lens used on the projector to determine the virtual scenes that have been made. Furthermore, some adjustments need to be made by changing the physical or virtual elements manually to get maximum results. In use, the details of the cross section and the building to be fired by the projector must be a concern to get the maximum effect. Special forms that have a cross section are used as the point of view of the graphics that are directed, so that the images will be more alive and have a value of interaction with visitors who see it. 


\subsection{Concept}

With social issues circulating in the community, video mapping uses collage animation that aims to be a means of entertainment and education for the people of Jakarta about the threat of turtle populations and the destruction of the marine ecosystem. Video mapping will be presented with a turtle-shaped cross section showing the visual variety as the main cross-section, followed by supporting visual ambience presented on the cube-shaped cross section in Figure 1. The collage animation video was created by following the appropriate mood board and visual references. Video mapping also played with back sound and sound effect for further enhancing the mood and experience.

\subsection{Venue}

The venue for video mapping is in Jakarta Aquarium at Acrylic Walkway zone. In this area, audience will feel the sense of walking into the ocean without getting wet.

\subsection{Cross Section Design}

The cross section is about waist height of an adult and viewable within 360 degrees. The main cross section which will be directed by a turtle-shaped body projection formed low-poly and has dimensions of 30x40x $25 \mathrm{~cm}$. Under the main section a cube-shaped cross section is used as a supporting mood ambience, sized 40x40x60 cm.

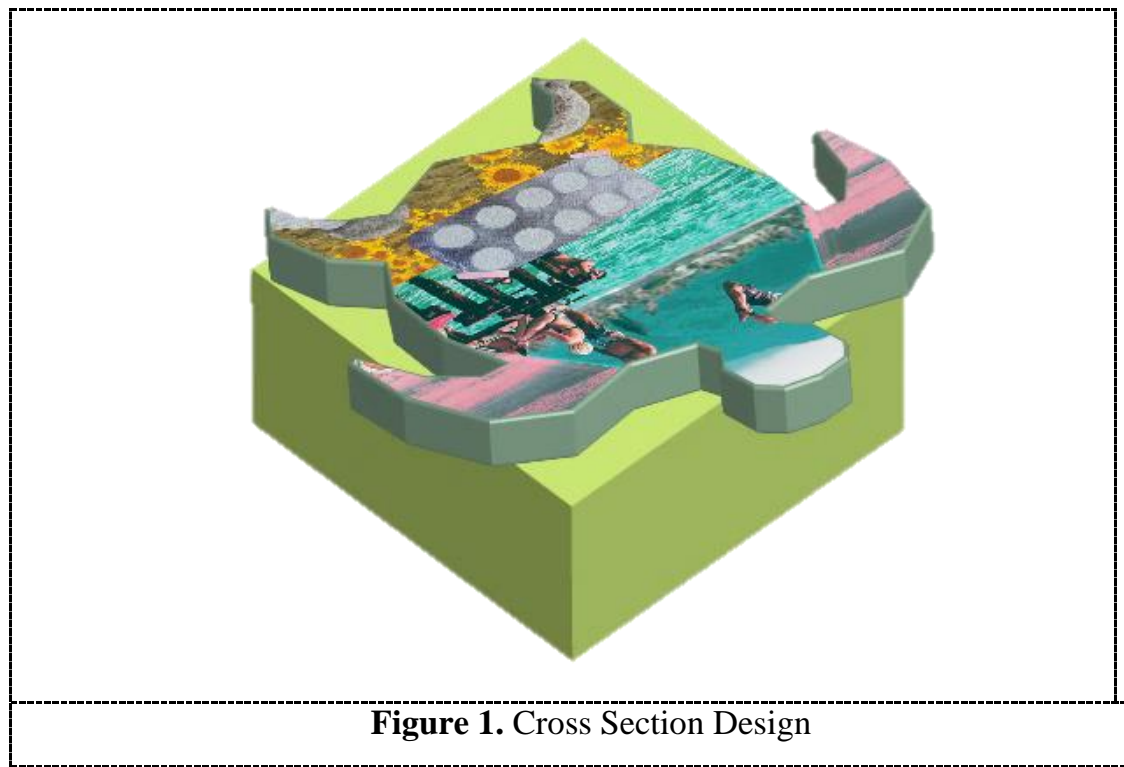

Cross sections will be projected from three different sources, enabling the visitors to see from all directions. The result of projection mapping onto three-dimensional objects can merge 2D graphics to become 3D graphics when it is interacted with applied surface [8]. The images are obtained from the licensed-free assets found across the internet and animated using Adobe After Effect software by playing opacity, shape, rotation, and other transformations.

\subsection{Mood board}

Mood board is a media design guide that will present images and photographs that contain atmosphere, colour and theme so that it illustrates the design results afterwards. Mood board is a tools used by designers to form an image that wants to be delivered to the audience to promote inspirations to develop suitable end-products [13]. The purpose of creating a mood board is to determine the direction of designing a video mapping, so that the visual and mood that will be delivered to the target audience. The visuals and moods to be delivered are feelings of compassion, fear, and discomfort, disturbing the calmness of the audience. 


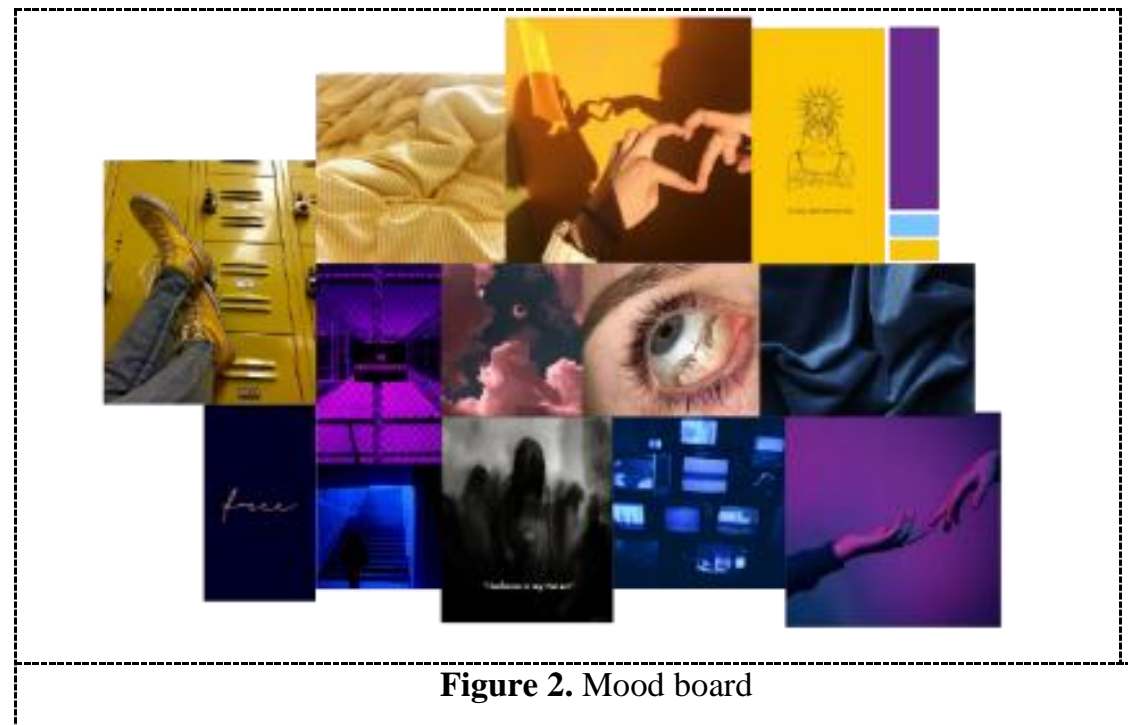

\subsection{Visual Treatment}

Visual treatment is an overview of the visual approach that will be presented later. In this video mapping design, a series of collage animated images are used. The images used for the animation itself are taken from royalty free image bank websites. The images then moved in motion using Adobe After Effect software with exploration in term of opacity, shape, rotation, and transformation usage.

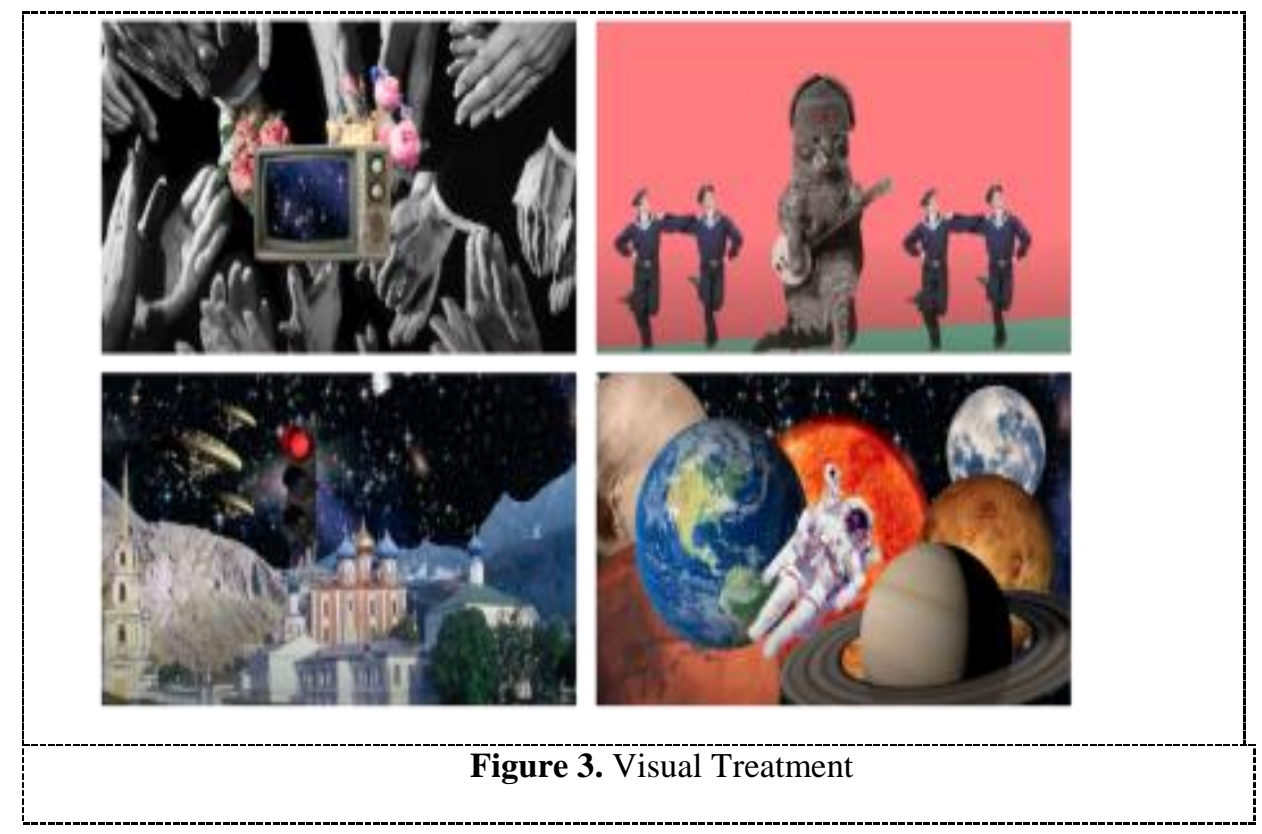

\subsection{Storyboard}

Storyboard is visuals displayed in sequence for the purpose of visualizing an animated film use in video mapping. As sequential art, storyboard is an arrangement of images to narrate a story or dramatize an idea [14]. Storyboard is an important phase in Pre-Production method. As digital storyteller, a storyboard gives guidance to narrative and expository texts through combining multiple media including images, voice, sound, transitions and movement. Visual effects (abbreviated VFX) and special effects (abbreviated SFX) added when needed to explain digital effects in storyboards. VFX is the process by which imagery is created or manipulated outside the context of a life action shot in film making. SFX used to create environments and inanimate objects [15]. The element of sound or backsound also added when needed to explain the alignment of audio and visual elements in storyboard. In many cases of audio for visual media, sound reinforces what is occurring on-screen, and the audience is subtly affected by the sound while they focus on the image [16].

This video mapping has two sets of storyboards. The first storyboard is for main video mapping and the second storyboards is for video ambience mood. The main video mapping aims to get people's perspective of sea turtle's life affected to waste pollution in their habitat. The visual and mood to be conveyed are feelings of compassion 
and discomfort of the audience by seeing the sea turtle's changing form. The calmness sound of the oceans breaks with cracking sound as added to the visuals. On the other hand, the video ambience mood aims to be a contrast of the main video mapping. The visual and mood to be conveyed are ideal cycle of nature that give happiness to the mankind.

Table 1 shows storyboard for main video mapping. Transitions show the sea turtle's changing form through movements from Scene 1 until Scene 4 in each duration of time. The main visual object is the sea turtle's body viewed from above. When the body cracked, it showed a lump of rubbish inside. It represents the impact of waste pollution to the life of sea turtle.
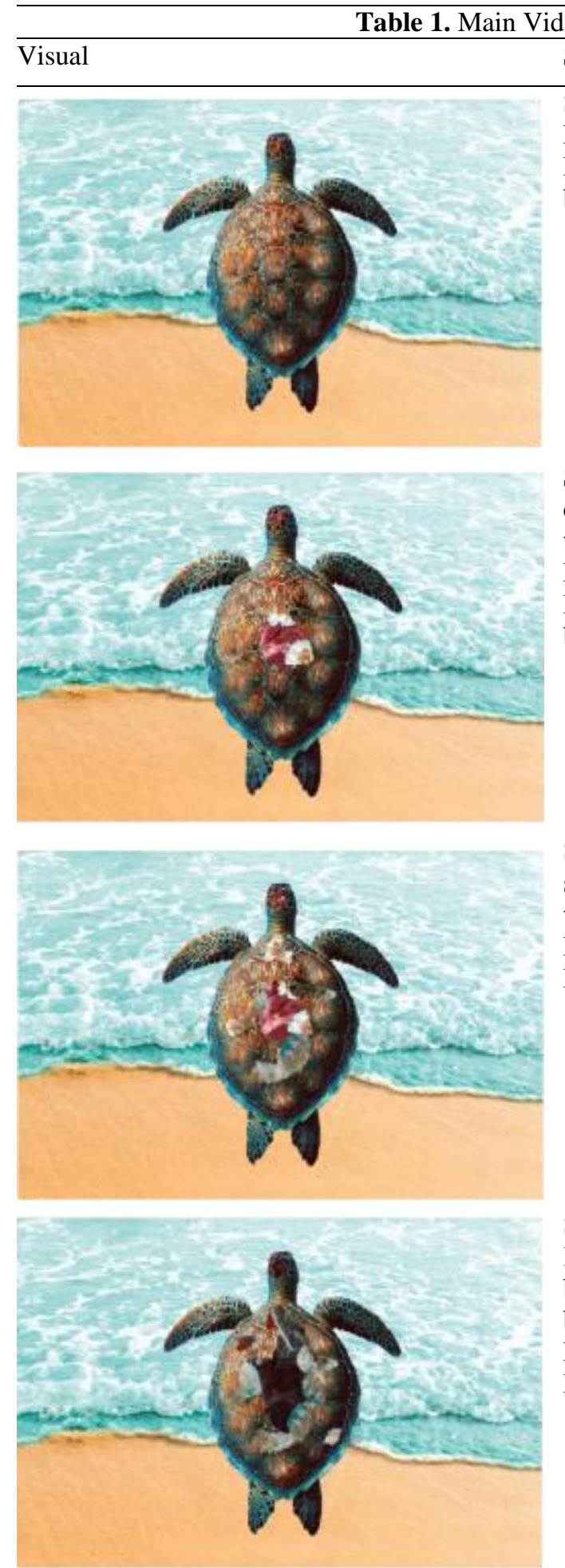

Scene 2: The sea turtle's shells start to cracking and showing the inside of the turtle's shells.

Duration: 40 seconds

Back sound: SFX cracking sound and beach ambience.

Scene 3: The cracked of the sea turtle's shell become larger and the inside of the turtle's shell is increasingly visible.

Duration: 45 seconds

Back sound: SFX cracking sound.

Scene 4: The sea turtle's shell cracked large and shows the garbage in the turtle's body and the sea turtle's heart is blackening.

Duration: 60 seconds

Back sound: SFX cracking sound. 
Table 2 shows storyboard for video ambience mood for supported mood ambience, shoot at the cube-shaped cross section under the main section. Interactive technology can be used to create all kinds of expressive mood manifestation [17]. Video ambience mood aims to create virtual environments to induce positive moods of the audience. The visual objects are various scene of habitats in nature including mountains, sea animals and creatures, flowers, and also shows object of human made such as doors and paper boat. It represents the connection between human and nature and how they affect each other in nature.

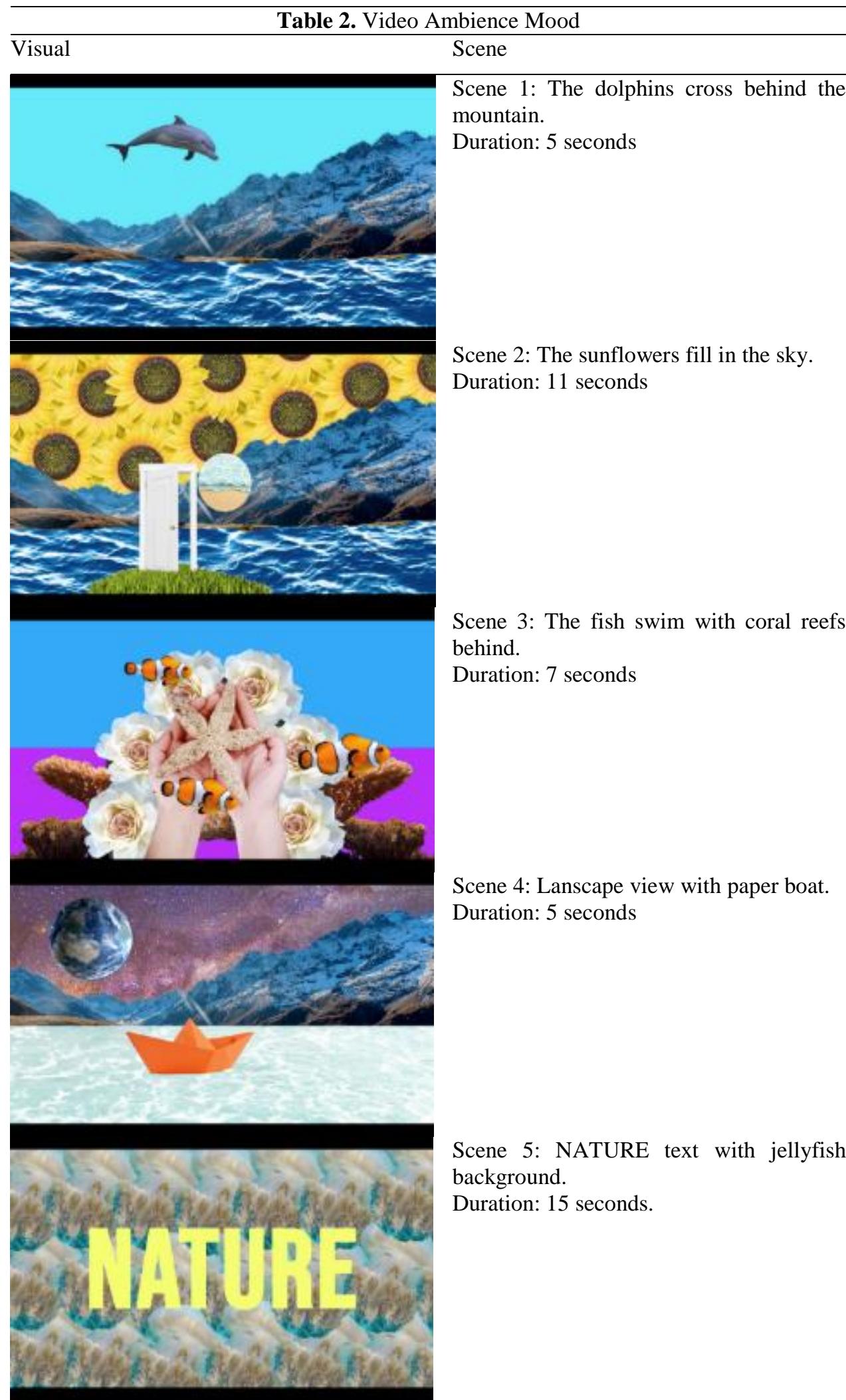




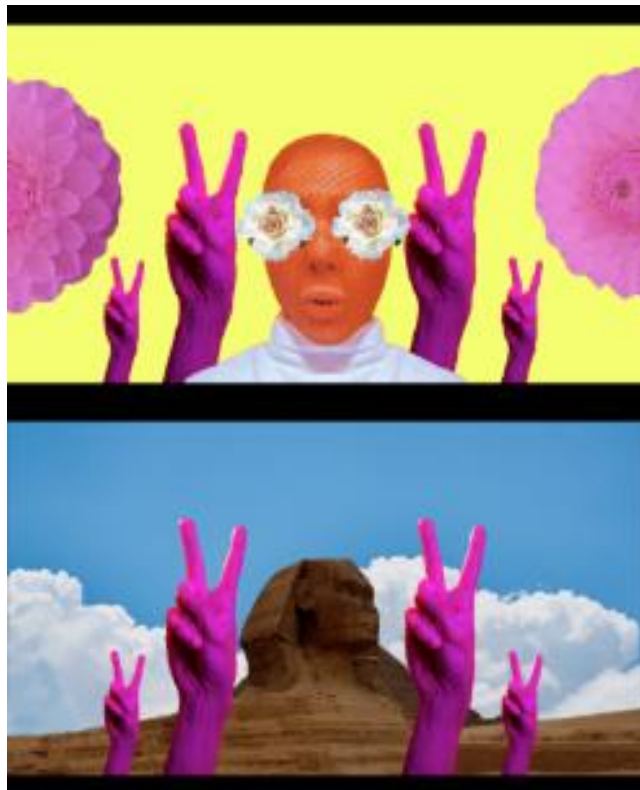

Scene 6: Women in fashion with circled flowers.

Duration: 11 seconds

Scene 7: The pyramid with hands.

Duration: 8 seconds

\subsection{Production}

The production phase is the next step of the video mapping process. The process is done by making a collage animation video according to the storyboard. This collage animation will be a visual display on the cross-section design. Animated video collages created using Adobe After Effect and Adobe Premiere software.

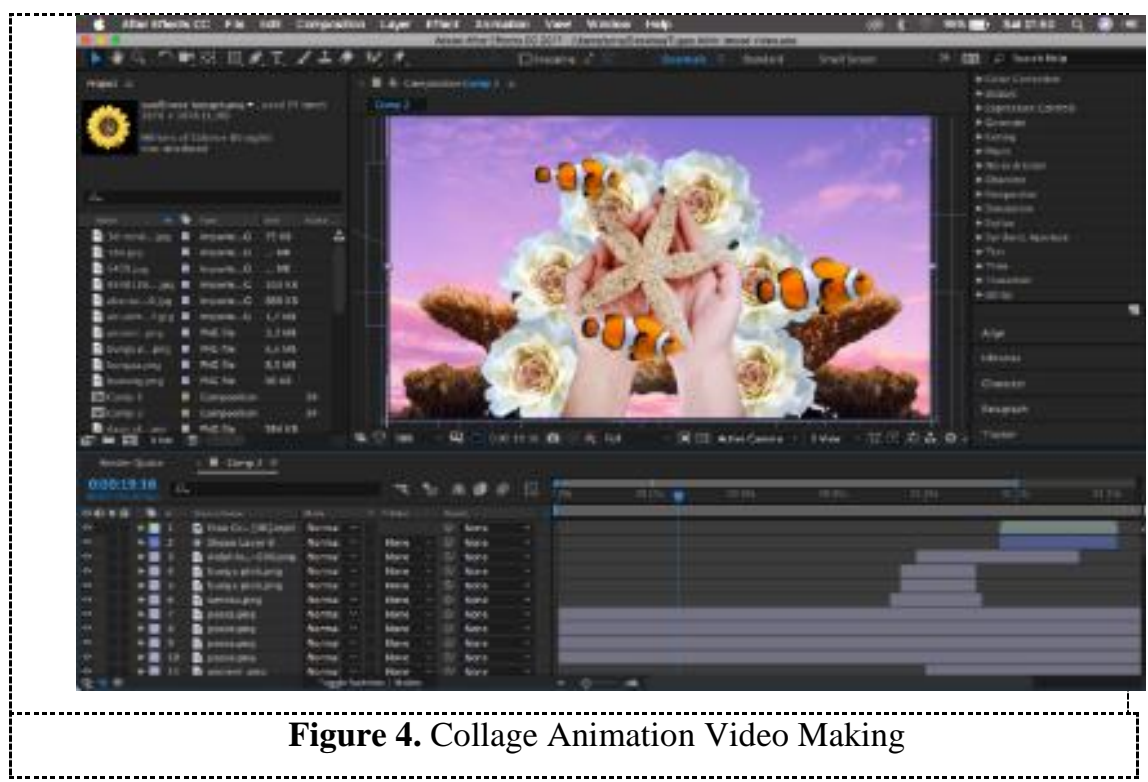

\section{Conclusion}

Concern for all components of society needs to be improved through methods and media that are able to attract the attention of the target audience. Video mapping is a new media can be used as education media to gain society's concern on environmental issues. One of the roles of visual communication designers is to produce visual solutions to educate the public through visual works that are able to inspire people who saw them. To increase the awareness and the general concern about the problem faced by sea turtles and their ecosystem habits, designers produced a conceptual video mapping design to be implemented in Jakarta Aquarium, one of Indonesia's metropolis best marine theme recreational educational venue. The video mapping concept as preproduction is sets of storyboards of collage animated video yet to be projected to the cross-section design surface. This concept adjusted by target and situations to be created in this design, aims to provide guidance to next production phase. The collage animation video made in production process will be use at sets and also promote 
through social media such as Instagram, Facebook and Twitter to get more involvement and to gain more awareness for preserving and protecting the natural environment.

\section{Acknowledgment}

The author acknowledges the support provided by the Faculty of Art and Design, Trisakti University, and the Research and Community Development Institution of Faculty of Art and Design, Trisakti University. The author also acknowledges the educational support provided by the Visual Communication Design Program, Faculty of Art and Design, Trisakti University, through the Final Project of Visual Communication Design Program

\section{References}

Lpsplsorong 2018 Penjaga Sumberdaya Itu Bernama Penyu Ber. Loka Pengelolaan Sumber Daya Pesisir Laut Sorong

Secretary-General R of the 2019 Sustainable Development Goal 14 Prog. Towar. Sustain. Dev. Goals

Mardiana E, Pratomo A and Irawan H 2013 Tingkat Keberhasilan Penetasan Telur Penyu Hijau (Chelonia mydas) Pulau Wie Tambelan di Lagoi (Universitas Maritim Raja Ali Haji)

Sunarto, Malawani M N, Sasongko M H D, Elvira I, Nastiti I P, P A and S A E 2019 A Geomorphological Evaluation of Sea Turtles Nesting in the Southern Sea of West Java IOP Conf. Series: Earth and Environmental Science 256 (IOP Publishing)

Hermawan D, Silalahi S and Eidman H M 1993 Studi Habitat Peneluran Penyu Sisik (Eretmochelys Imbricata L) di Pulau Peteloran Timur dan Barat Taman Nasional Kepulauan Seribu, Jakarta J. Ilmu-ilmu Perair. dan Perikan. Indones. $133-7$

ProFauna 2017 Catat, Ternyata Ini Fungsi Penyu Bagi Kehidupan ProFauna.net

Puspitaningrum R, Muthmainnah Z, Darmastuti S and Larassati A 2019 Efectivity of Sea Turtle Watch Program to Increase Student's Knowledge About Sea Turtle Conservation in Pramuka Island IOP Conf. Series: Earth and Environmental Science 241 (IOP Publishing)

Ekim B 2011 A Video Projection Mapping Conceptual Design and Application: Yekpare Turkish Online J. Des. Art Commun. - TOJDAC 1 10-9

Anon 2020 Jakarta Aquarium Jakarta-Aquarium.com

Trio S N 2009 Kampanye Pelestarian Penyu Sisik di Kawasan Kepulauan Seribu (Universitas Komputer Indonesia)

Binanto I 2020 Multimedia Digital - Dasar Teori dan Pengembangannya (Yogyakarta: CV Andi Offset)

Guo Y, Chu S-C, Liu Z, Qiu C, Luo H and Tan J 2018 A real-time Interactive System of Surface Reconstruction and Dynamic Projection Mapping with RGB-depth sensor and projector Int. J. Distrib. Sens. Networks 14 112

Cassidy T 2011 The Mood Board Process Modeled and Understood as a Qualitative Design Research Tool J. Des. Creat. Process Fash. Ind. $3225-51$

Mou T-Y, Jeng T-S and Chen C-H 2013 From Storyboard to Story: Animation content development Acad. Journals Educ. Res. Rev. 8 1032-47

Pardeshi A S and Karbhari V B 2019 Recent Trends in VFX (Virtual Effects) and SFX (Special Effects) Int. J. Eng. Res. Technol. 8 882-4

Collins K 2009 Generating Meaningful Sound: Quantifying the Affective Attributes of Sound Effects for RealTime Sound Synthesis in Audio-Visual Media Audio Engineering Sociely 35th International Conference (London)

Desmet P M A 2015 Design for Mood: Twenty Activity-Based Opportunities to Design for Mood Regulation Int. J. Des. 9 